QRU 1 / 11 



\section{EL ESPACIO PÚBLICO CONTRA LA CALLE Manuel DELGADO}

¿Qué entendemos hoy por espacio público? Consideremos tres de sus acepciones posibles. La definición que designaríamos como A entendería espacio público como escenario de y para las "relaciones públicas" o "en público", un tipo específico de vida social en el que los concurrentes se someten a las iniciativas y juicios ajenos y conforman configuraciones transitorias, pero estratégicas, protagonizadas en buena parte por desconocidos totales o relativos, en un régimen de visibilidad generalizada. Ese es el valor que tiene espacio público en la tradición interaccionista y microsociológica, tal y como la encarnan autores que heredan el interés de Simmel y la Escuela de Chicago por la situación como unidad de análisis, como Erving Goffman, John y Lyn Lofland o Isaac Joseph, por hacer referencia sólo a algunos autores. Ese espacio no es tanto un lugar como un "tener lugar", un proceso ni finalista ni finalizado de apropiaciones innumerables y en buena medida reguladas endógenamente, concreción del concepto kantiano de espacio como "posibilidad de juntar". Ese espacio no está antes, sino luego de los usos que lo recorren y los acaeceres que no deja de registrar. En el plano empírico, se asociaría con la calle, la plaza y otros escenarios análogos, espacios colectivos por antonomasia en los que nos es dado contemplar lo social "manos a la obra", es decir el interminable trabajo de lo social sobre sí mismo, haciéndose y deshaciéndose sin descanso.

En paralelo, espacio público tiene otro sentido en manos de la filosofía política, que lo entiende como una categoría abstracta derivada de la noción ilustrada de publicidad, esfera ideal para la coexistencia pacífica de lo heterogéneo de la sociedad, ámbito de y para el libre acuerdo entre seres autónomos y emancipados que se vinculan a partir de pactos reflexivos permanentemente reactualizados, individuos libres e iguales que critican, valoran y fiscalizan los poderes políticos, al mismo tiempo que se entienden a partir de su capacidad para argumentar y pactar entre sí. Ese ámbito es aquel en el que se despliegan los principios éticos de la civilidad, la ciudadanía y demás virtudes en que funda su posibilidad la democracia igualitaria y que surge como consecuencia de determinados cambios en la estructura de las relaciones políticas que se produce en el siglo XVIII. Los autores de referencia aquí serían Hannah Arendt, Reinhardt Koselleck y Jürgen Habermas, para quienes el espacio público seria sobre todo un dominio teórico al que no cabe atribuir una especialización concreta. Esa sería la definición B.

Tendríamos una tercera acepción a considerar aquí: la $\mathrm{C}$, el espacio público como espacio de titularidad pública, conjunto de elementos inmuebles y arquitectónicos sometidos a la administración del Estado, que debe garantizar su accesibilidad para todos sin excepción, para lo cual legisla y normativiza a 
propósito de las buenas prácticas que legitiman su disfrute, lo protegen del interés privado y cuidan de su conservación. Desde esa perspectiva espacio público son la plaza, la calle, el parque, la playa y otros vacíos urbanos, pero también contenedores institucionales, gestores, culturales, educativos, sociales, etc. En España el espacio público está definido y regulado por la Ley 9 de 1989 y por al artículo 2 del Decreto 1504/98, así como por normativas municipales que se presentan habitualmente como "de ciudadanía" o "de civilidad", destinadas a establecer cuáles son sus usos adecuados y aceptables y cuáles deben ser objeto de sanción. De esa acepción se deriva también el concepto penal de "orden público", cuya alteración conlleva consecuencias penales.

Lo interesante es constatar como la incorporación en las tres últimas décadas -y no mucho más allá- del concepto de espacio público al discurso teórico y la práctica profesional de urbanistas y arquitectos ha implicado una suerte de sobreposición o confusión entre el espacio hiperconcreto A -la calle y la plaza como quintaesencia del espacio social- y el espacio metafísico B, asociado al proyecto republicano de sociedad civil. La realización de esa síntesis es una misión asignada por los detentadores del espacio legal C -la administración política y las elites cuyos intereses económicos y de legitimación simbólica ejecuta- en orden a elevar el tono moral de los territorios urbanos de su propiedad, crecientemente puestos a la venta como suelo o como paisaje. Todo ello enmarcado en las grandes dinámicas de gentrificación, terciarización y tematización que están viviendo las ciudades contemporáneas, procesos cuyo arranque coincide precisamente con la irrupción con fuerza de la noción de espacio público en los enunciados discursivos urbanísticos y arquitectónicos que han acompañado las intervenciones sobre huecos urbanos.

El diseño de ciudades desde la arquitectura y el urbanismo recibe de la polis el encargo de caracterizar, diferenciar y calificar no sólo formalmente un determinado territorio, sino también ética e incluso jurídicamente. En este caso, de lo que se ha tratado es de asignar una plusvalía simbólica, un valor de alguna manera superior, a los espacios urbanos, en el sentido de los espacios de y para lo urbano, rescatándolos de su opacidad crónica, redimiéndolos de lo tenían de paradójico, contradictorio, fragmentario... Objetivo: convertir lo que era -la maraña autogestionada de aconteceres que conoce la calle- en lo que debía ser, esto es la sustantivización espacial de los ideales del igualitarismo democrático oficial esa noción de espacio público como marco de y para lo social no como estructura, sino como proceso permanente e inacabado de estructuración es casi lo contrario de aquella otra que se empeña en realizar empíricamente lo que no puede ser más que una quimera, el sueño imposible de una confiada clase media universal que desearía vivir en un mundo todo él hecho de consensos negociados y de intercambios comunicacionales puros entre seres libres, iguales y responsables.

El espacio público A -la calle, la plaza- no es el mero resultado de una determinada morfología, sino ante todo de una articulación de cualidades sensibles que resultan de las operaciones prácticas y las esquematizaciones tempo-espaciales en vivo que procuran sus usuarios. En ese espacio el conflicto es un ingrediente casi consustancial. Es más: vive de él, se alimenta de lo mismo que no deja nunca de alterarlo. En el espacio público B, en cambio, el conflicto es inconcebible, puesto que existe para negar y mostrar como 
monstruosa su mera insinuación. En él sólo caben aquellos que estén en condiciones de confirmar la ficción de un terreno neutral en el que segmentos sociales con identidades e intereses incompatibles han decretado una tregua indefinida en sus luchas.

La operación proyectual en "espacios públicos de calidad" no hace sino brindar un nuevo vehículo de expresión y actuación a la antigua agorafobia de los poderes, siempre ávidos por domeñar lo urbano como máquina azarosa e imprevisible, siempre predispuesta al desacato, nunca plenamente gobernable. Se sabe que una ciudad sólo puede ser puesta a la venta si se ha sido capaz de pacificarla antes, de demostrar que está dispuesta a someterse y obedecer. Para ello ha sido dispuesto ese nuevo artefacto categorial que es el "espacio público", del que políticos y filósofos brindan la ideología y al servicio del cual, en orden a su reificación física como lugar, los diseñadores de ciudad conciben formas, imponen jerarquías, distribuyen significados, determinan o creen determinar usos. Pero, indiferente a teorías, planos y planes, a ras de suelo, afuera, mientras tanto, nada puede impedir que continúen multiplicándose los trasiegos y entrecruzamientos infinitos de cuerpos y miradas, el merodeo de las multitudes, la amenaza de lo inconstante, todo aquello que hasta no hace mucho nos atrevíamos a llamar sencillamente la calle. 